\title{
Ida Oggiano. "At the Courts of Omri of Samaria and Eshmunazor II of Sidon. Objects, Images, and Court Style"
}

\section{Astrid Nunn}

\author{
(2) OpenEdition \\ Journals \\ Édition électronique \\ URL : http://journals.openedition.org/abstractairanica/49490 \\ DOI : $10.4000 /$ abstractairanica. 49490 \\ ISBN : 1961-960X \\ ISSN : 1961-960X \\ Éditeur : \\ CNRS (UMR 7528 Mondes iraniens et indiens), Éditions de l'IFRI
}

Référence électronique

Astrid Nunn, «Ida Oggiano. "At the Courts of Omri of Samaria and Eshmunazor II of Sidon. Objects, Images, and Court Style" », Abstracta Iranica [En ligne], Volume 40-41 | 2019, document 64, mis en ligne le 30 octobre 2019, consulté le 23 avril 2021. URL : http://journals.openedition.org/abstractairanica/ 49490 ; DOI : https://doi.org/10.4000/abstractairanica.49490

Ce document a été généré automatiquement le 23 avril 2021.

Tous droits réservés 
Ida Oggiano. "At the Courts of Omri of Samaria and Eshmunazor II of Sidon. Objects, Images, and Court Style"

Astrid Nunn 


\section{RÉFÉRENCE}

Ida Oggiano. "At the Courts of Omri of Samaria and Eshmunazor II of Sidon. Objects, Images, and Court Style" in Gianto, Agustinus, Peter Dubovský (eds.). Changing Faces of Kingship in Syria-Palestine 1500-500 BCE. Münster: Ugarit Verlag, 2018, p. 139-163 (AOAT 459)

1 Le volume de 206 pages dans lequel le présent article a paru, est le résultat d'un séminaire titré "Changing Faces of Kingship in Syria-Palestine, 1500-500 BCE" à l'Institut Pontifical Biblique de Rome en décembre 2015. Les contributions traitent du concept de la royauté en Égypte, à l'époque d'Amarna, au royaume de Mittani, à Sam'al et en Judée assyrienne.

2 Seule la contribution de Ida Oggiano s'inscrit dans le cadre des d'Abstracta. L'A. tente d'interpréter le matériel imagé connu de la cour (pré-achéménide) de Samarie et achéménide de Sidon sous l'aspect du pouvoir. La royauté phénicienne de Sidon à l'époque perse fait face à deux tendances: une conscience phénicienne et une cosmopolisation. Le fait d'appartenir à l'Empire achéménide pousse ou oblige les rois phéniciens à s'intégrer dans un "mode» plus international et dicté d'ailleurs. Le langage symbolique s'élargit. En ceci la royauté de Sidon diffère profondément des royautés du Fer II, à qui la plus grande indépendance avant les Assyriens permettait d'exprimer leur propre tradition - en mots et en images.

\section{AUTEURS}

\section{ASTRID NUNN}

Université de Munich 